\title{
PICK1 wt Allele
}

National Cancer Institute

\section{Source}

National Cancer Institute. PICK1 wt Allele. NCI Thesaurus. Code C134683.

Human PICK1 wild-type allele is located in the vicinity of 22q13.1 and is approximately 19 $\mathrm{kb}$ in length. This allele, which encodes PRKCA-binding protein, plays a role in the trafficking and internalization of signaling receptors. 